\title{
The Distribution of Magnesium in Developing Rat Incisor Dentin
}

\section{J. STEINFORT, F.C.M. DRIESSENS ${ }^{1}$, H.J.M. HEIJLIGERS ${ }^{2}$, and W. BEERTSEN}

Experimental Oral Biology Group, Department of Periodontology, Academic Centre for Dentistry Amsterdam (ACTA), Louwesweg 1, 1066 EA Amsterdam, The Netherlands; ${ }^{1}$ Department of Oral Biomaterials, Faculty of Dentistry, Catholic University, Nijmegen; and ${ }^{2}$ Department of Physical Chemistry, University of Technology, Eindhoven

Previous studies have shown that rat incisor dentin contains a considerable amount of magnesium that is distributed heterogeneously. The cementum-related dentin, especially its incisal portion, is richest in magnesium. It was the purpose of the present study to investigate the changes that occur in the magnesium content during dentin maturation.

Cross-sections were prepared from rat incisors at the apical, middle, and incisal levels. By means of an electron microprobe, tracings were made of the $\mathrm{Ca}-, \mathrm{Mg}$-, and $\mathrm{P}$ - signal frequencies. Comparison of corresponding dentin layers within and between the cross-sections showed that the $\mathrm{Mg} / \mathrm{P}$ molar ratio was always higher in the cementum-related dentin (CRD) than in the enamel-related dentin (ERD) and increased from the apex toward the incisal edge. Especially in the incisal crosssection, an increase in $\mathrm{Mg} / \mathrm{P}$ was found from the older (peripheral) toward the younger (central) dentin layers. As the $\mathrm{Mg} / \mathrm{P}$ ratio varied from 0.07 to 0.33 , the $\mathrm{Ca} / \mathrm{P}$ ratio was found to fluctuate from 1.48 to 1.15 . The two ratios appeared to be highly correlated $(r=-0.97 ; p<0.001)$, suggesting that $\mathrm{Mg}$ replaces $\mathrm{Ca}$ and is bound to phosphate.

\section{J Dent Res 70(3):187-191, March, 1991}

\section{Introduction.}

The contribution of magnesium to biomineralization is unclear. In a number of calcified tissues, such as rat incisor enamel (Hiller et al., 1975), cutaneous calcinosis (Tochon-Danguy et al., 1978), fracture callus, and turkey tendon (Quint et al., 1980 ), the magnesium concentration strongly diminished as the mineralization process evolved. The presence of magnesium in the early stages was accompanied by an elevated carbonate content (Hiller et al., 1975; Quint et al., 1980).

In rat incisor dentin, the magnesium content increases as a function of time (Johnson, 1972; Steinfort et al., 1990). In previous studies, we have demonstrated that in the rodent incisor two dentin portions can be distinguished, an enamel- and a cementum-related one (ERD and CRD, respectively), which differ with respect to their mineralization rates (Beertsen and Niehof, 1986) and the composition of their organic and inorganic matrices (Steinfort et al., 1989, 1990). The ERD is harder and denser and contains more calcium and phosphate but less magnesium, as compared with the CRD. In addition, the ERD was found to be richer in phosphoproteins with a higher degree of phosphorylation than the CRD, which led us to suggest that different control mechanisms may exist with respect to mineralization in the two dentins. It was the purpose of the present study to investigate in more detail the incorporation of magnesium during dentin formation in the ERD and CRD.

\section{Materials and methods.}

Preparation of specimens. - Ten female Wistar rats (four months old) were anesthetized with ether and killed by an

Received for publication January 23, 1990

Accepted for publication January 5, 1991 overdose of Nembutal injected intracardially. Their lower right jaws were dissected out and stored frozen. Cross-sectional slices (1 mm in thickness) of the incisors, together with the surrounding tissues, were prepared at an apical, middle, and incisal level (Fig. 1) by use of a Microslice 2 MR (Metals Research Ltd., Cambridge, England) with a diamond saw blade under constant water cooling. After removal of the surrounding bone, the cross-sections of the incisors were dehydrated through a graded series of ethanol and propyleneoxide and embedded in epoxy resin (Epon LX112, Ladd), which was polymerized at $60^{\circ} \mathrm{C}$. All specimens were embedded simultaneously in the same piece of epoxy resin, in such a way that the slices obtained from one tooth were next to each other. The incisal aspect of each slice was then serially polished with silicon carbide abrasive paper (nos. 240 to 600 ), followed by a 0.03 $\mu \mathrm{m}$ aluminum oxide micropolisher.

Electron microprobe analysis. - After the slices were coated with a carbon layer in a Balzer BEA 250 evaporator, the specimens were subjected to electron microprobe analysis in a JEOL Superprobe $733\left(10 \mathrm{kV}, 10 \mu \mathrm{A}\right.$, beam area $1 \mu \mathrm{m}^{2}$, ten s per

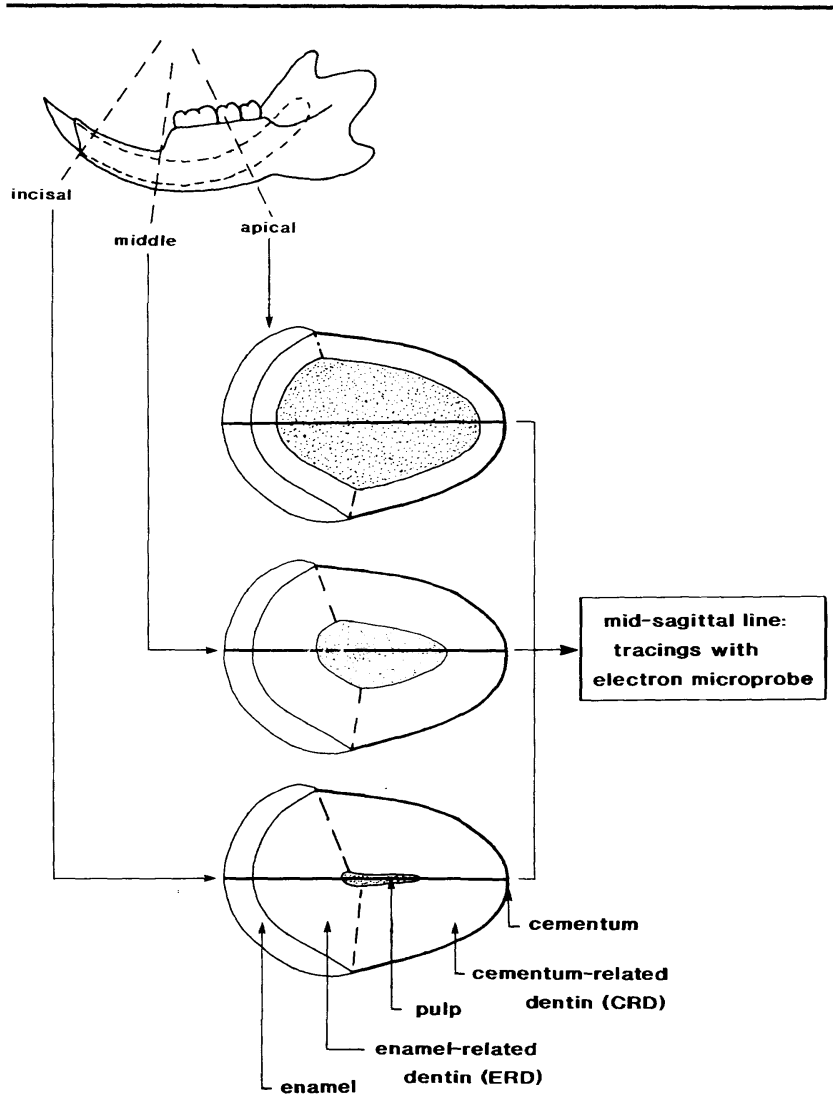

Fig. 1 - Rat lower incisor cross-sectioned at the apical, middle, and incisal levels. Electron microprobe tracings were made along the midsagittal line of each cross-section. ERD = enamel-related dentin. CRD $=$ cementum-related dentin. 
measurement, automatic background subtraction). Tracings of calcium, magnesium, and phosphorus were made at 3-, 7-, and $10-\mu \mathrm{m}$ intervals (apical, middle, and incisal cross-sections, respectively) along the mid-sagittal line (Fig. 1). Of four slices obtained from the incisal level, tracings were also made along para-sagittal lines.

Signal count ratios of $\mathrm{Mg}, \mathrm{Ca}$, and $\mathrm{P}$ were calculated at intervals of about $25 \mu \mathrm{m}$. The signal counts along the outer and inner edges of the incisor showed considerable fluctuations. For this reason, a zone of $15 \mu \mathrm{m}$ along the borderlines was excluded from the analysis. As a consequence, pre-dentin (width, ca. $15 \mu \mathrm{m}$ ) and cementum (width, $c a .2 \mu \mathrm{m}$ ) were not included in the present study.

Molar ratios were calculated from signal count ratios by comparison with tracings of standards of known composition (apatite and pyrope; chemical analysis by Micro-analysis Consultants, St. Ives, England).

$Z A F$ correction. - The molar ratios mentioned above, as determined by electron microprobe, are subject to variations in density and composition of the dentin material. In order to determine the extent to which this occurred, the composition of epoxy-resin-embedded dentin was calculated for a series of mineral contents ranging from 10 to $75 \%$ (wt/wt) and $\mathrm{Mg} / \mathrm{Ca}$ molar ratios varying between 0.03 and 0.30 . ZAF corrections were then calculated by the Proza correction program (Bastin and Heijligers, 1990) for dentin-on the basis of C, N, O, Cl, $\mathrm{P}, \mathrm{Ca}$, and $\mathrm{Mg}$ - and for the standards.

Corrections between -0.1 and $+1.8 \%$ for $\mathrm{Ca} / \mathrm{P}$ and between +5.4 and $+6.4 \%$ for $\mathrm{Mg} / \mathrm{P}$ were found as the dentin varied from highly mineralized and low in magnesium toward poorly mineralized and high in magnesium.

Because these values influence the results to only a minor degree, it was considered unnecessary to calculate corrections for all individual measurements. The ratios presented in the results are the uncorrected data.

Statistics. - Because the ratios calculated showed skewed distributions, the results were tested by Wilcoxon's signedrank test for paired observations and Spearman's correlation coefficient of rank correlation.

\section{Results.}

Distribution of $\mathrm{Mg} / \mathrm{P}$ and $\mathrm{Ca} / \mathrm{P}(\mathrm{mol} / \mathrm{mol})$ in dentin within cross-sections. - In the middle and incisal, but not in the apical, cross-sections, the $\mathrm{Mg} / \mathrm{P}$ ratio tended to increase from the outer dentin toward the pulp (Fig. 2). However, in the dentin most adjacent to the pulp, $\mathrm{Mg} / \mathrm{P}$ tended to decrease again. This effect was most prominent in the CRD. The increase in $\mathrm{Mg} / \mathrm{P}$ was statistically significant at the incisal level, especially in the ERD (ERD, $r=0.94 ; \mathrm{p}<0.001 ; \mathrm{CRD}, \mathrm{r}=0.55 ; \mathrm{p}<0.001$ ).

The $\mathrm{Ca} / \mathrm{P}$ (Fig. 3) ratio showed inverse tendencies with respect to the $\mathrm{Mg} / \mathrm{P}$ ratio. At the middle and incisal levels, a decrease from the outer dentin toward the pulp was observed, followed by an increase in the dentin most adjacent to the pulp. The decrease in $\mathrm{Ca} / \mathrm{P}$ was statistically significant at the incisal level (ERD, $\mathrm{r}=-0.95 ; \mathrm{p}<0.001 ; \mathrm{CRD}, \mathrm{r}=-0.54$; $\mathrm{p}<0.001)$.

The ERD contained more $\mathrm{Ca} / \mathrm{P}(\mathrm{p}<0.01)$ and less $\mathrm{Mg} / \mathrm{P}$ $(p<0.01)$ than the CRD when corresponding measuring sites were compared. This was the case at all three levels.

Tracings along para-sagittal lines (not shown) revealed similar distribution patterns of $\mathrm{Mg} / \mathrm{P}$ and $\mathrm{Ca} / \mathrm{P}$ as found for the mid-sagittal lines. The inclinations, however, were less steep because of the oblique intersections of these lines with the concentric dentin zones.

Comparison of $\mathrm{Mg} / \mathrm{P}$ and $\mathrm{Ca} / \mathrm{P}(\mathrm{mol} / \mathrm{mol})$ in dentin between cross-sections. Effects of time. - Comparison of the outer dentin zones of the apical, middle, and incisal levels showed an increase in $\mathrm{Mg} / \mathrm{P}$ with dentin aging. The same was observed when the middle zones of the middle and incisal levels were compared with each other (Fig. 2, open arrows; $p<0.01$ ). This was not the case for enamel.

With respect to $\mathrm{Ca} / \mathrm{P}$ (Fig. 3, open arrows), a comparison of the outer dentin zones at the apical and middle levels showed a decrease in $\mathrm{Ca} / \mathrm{P}$ in the $\mathrm{CRD}(\mathrm{p}<0.01)$. The same was observed when the middle zones of the middle and incisal levels were compared $(\mathrm{p}<0.05)$. A similar tendency, although not statistically significant, was found for the ERD.

Effects of site. - Comparison between the dentin zones most adjacent to the pulp (marked "1.") at the apical, middle, and incisal levels (all of which were formed at the same time) revealed that $\mathrm{Mg} / \mathrm{P}$ increased in the incisal direction (Fig. 2; $\mathrm{p}<0.01$ ). The reverse was found for $\mathrm{Ca} / \mathrm{P}$ (Fig. $3 ; \mathrm{p}<0.02$ ).

Relation between calcium and magnesium. - The distribution patterns of $\mathrm{Mg} / \mathrm{P}$ and $\mathrm{Ca} / \mathrm{P}$ were found to be highly complementary. The value of $(\mathrm{Mg}+\mathrm{Ca}) / \mathrm{P}$ varied only slightly with the distance from the pulp and was nearly the same in all cross-sections (not shown).

When $\mathrm{Ca} / \mathrm{P}$ was plotted against $\mathrm{Mg} / \mathrm{P}$ (Fig. 4), it appeared that the two ratios showed an almost perfect negative correlation $[\mathrm{r}=-0.80,-0.91$, and $-0.97(\mathrm{p}<0.001)$ for the apical, middle, and incisal levels, respectively]. At the incisal level, but not at the other levels, a negative correlation was also found between $(\mathrm{Mg}+\mathrm{Ca}) / \mathrm{P}$ and $\mathrm{Mg} / \mathrm{P}(\mathrm{r}=-0.63)$, which was hardly affected by ZAF correction $(\mathrm{r}=-0.56)$. The latter correlation indicates that although $\mathrm{Mg} / \mathrm{P}$ and $\mathrm{Ca} / \mathrm{P}$ are inversely related, $\mathrm{Mg}$ is not merely replacing $\mathrm{Ca}$ on a 1:1 molar basis.

\section{Discussion.}

The present study has shown that the difference in $\mathrm{Mg} / \mathrm{P}$ ratio between ERD and CRD is already present in the youngest dentin layers and is maintained throughout the maturation process. These findings further substantiate the notion that intrinsic differences exist in the rodent incisor between the ERD and CRD with respect to formation and mineralization of dentin (Beertsen et al., 1985; Beertsen and Niehof, 1986; Steinfort et al., 1989, 1990).

The results of this study have further shown that the maturation of the outer and middle dentin layers is accompanied by a rise in the $\mathrm{Mg} / \mathrm{P}$ ratio. In the $\mathrm{CRD}$, this increase in $\mathrm{Mg}$ was accompanied by a concomitant fall in the $\mathrm{Ca} / \mathrm{P}$ ratio. In the $E R D$, the decrease in Ca was less evident than the increase in Mg. Comparison of the youngest dentin zones at the three levels studied revealed that the highest $\mathrm{Mg} / \mathrm{P}$ ratios and the lowest $\mathrm{Ca} / \mathrm{P}$ ratios were found at the incisal level. With respect to the ERD, the latter finding is in line with the work of Johnson (1972). In a previous study (Steinfort et al., 1990), we found that at least $99 \%$ of the calcium and phosphate is inorganic, which implies that the differences mentioned above are related mainly to the mineral and not to the organic matrix. This is also likely to be the case with magnesium, since the concentration of magnesium in the incisal segment of the dentin cylinder was found to be as much as $7 \%(\mathrm{w} / \mathrm{v})$. Furthermore, it was shown that whereas the overall mineral density of the dentin cylinder showed a 30\% increase from the apical toward the incisal segment, the increase in magnesium was five times as large (Steinfort et al., 1990).

A striking observation was the almost-perfect negative correlation between the $\mathrm{Mg} / \mathrm{P}$ and $\mathrm{Ca} / \mathrm{P}$ ratios (Fig. 4), the $\mathrm{Mg} / \mathrm{P}$ ratio ranging from 0.07 to 0.33 and the $\mathrm{Ca} / \mathrm{P}$ ratio from 1.48 


\section{$\mathrm{Mg} / \mathrm{P}(\mathrm{mol} / \mathrm{mol})$}

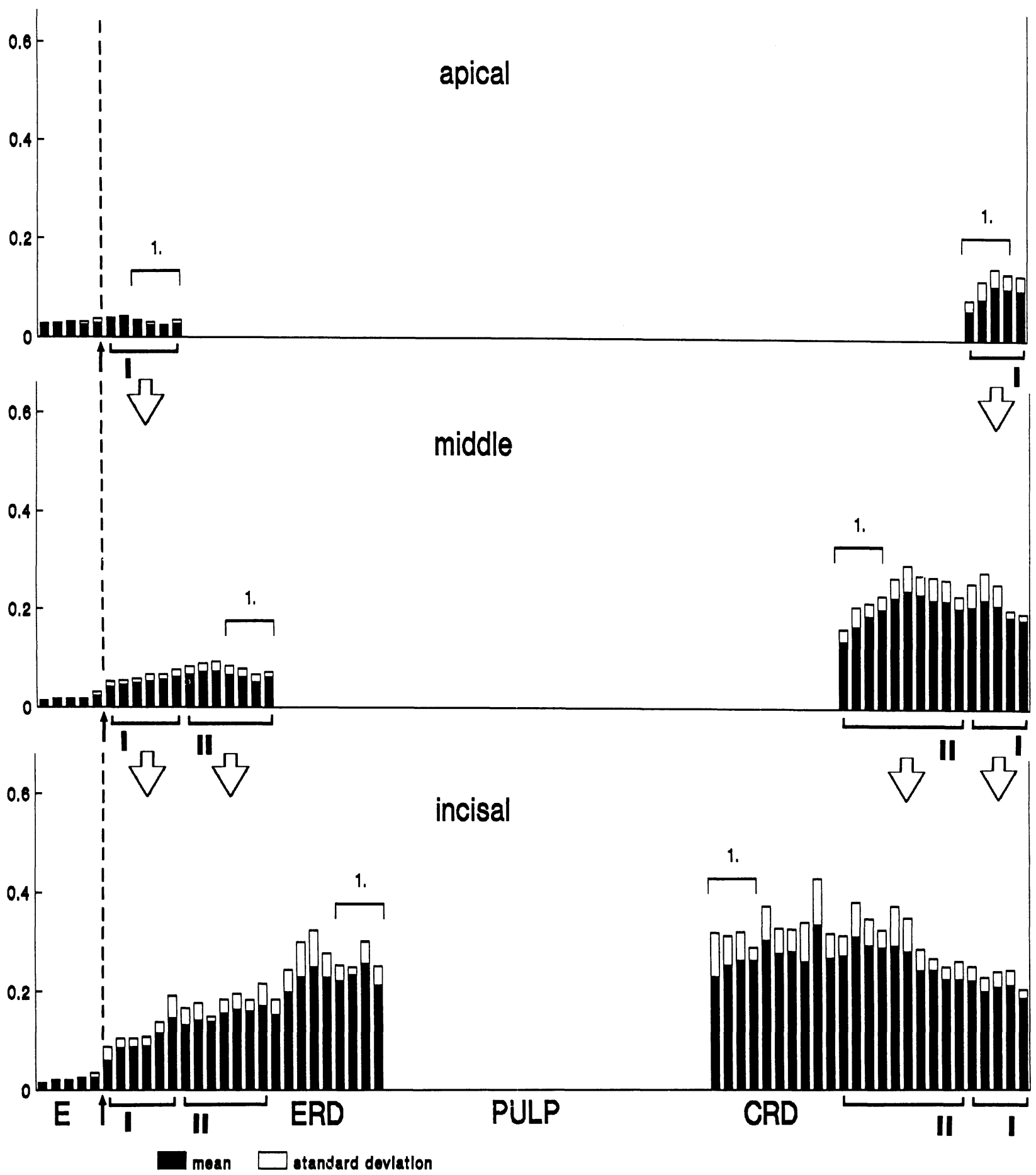

Fig. $2-\mathrm{Mg} / \mathrm{P}$ molar ratio along the mid-sagittal line (see Fig. 1) of the apical, middle, and incisal cross-sections. Measurements were made at 25 $\mu \mathrm{m}$ intervals (mean + S.D.; $\mathrm{n}=10$ ). $\mathrm{E}=$ enamel; closed arrows = dentin-enamel junction; $\mathrm{I}=$ outer dentin zone; $\mathrm{II}=$ middle dentin zone; 1 . = dentin zone most adjacent to the pulp. The open arrows indicate sequential maturation stages of the dentin $(p<0.01)$. The measurements of pre-dentin and cementum are not presented in this Fig.

to 1.15. Furthermore, the ERD contained less magnesium than the CRD. Both findings are in line with our previous work (Steinfort et al., 1990). Low Ca/P ratios in rat incisor dentin have also been reported by Höhling et al. (1968). An increas- ing $\mathrm{Mg} / \mathrm{P}$ ratio from the outer dentin zone toward the center has also been observed in the teeth of man and the monkey (Shaw and Yen, 1972).

The rise in $\mathrm{Mg}$ in the aging outer dentin layers can be ex- 


\section{$\mathrm{Ca} / \mathrm{P}(\mathrm{mol} / \mathrm{mol})$}

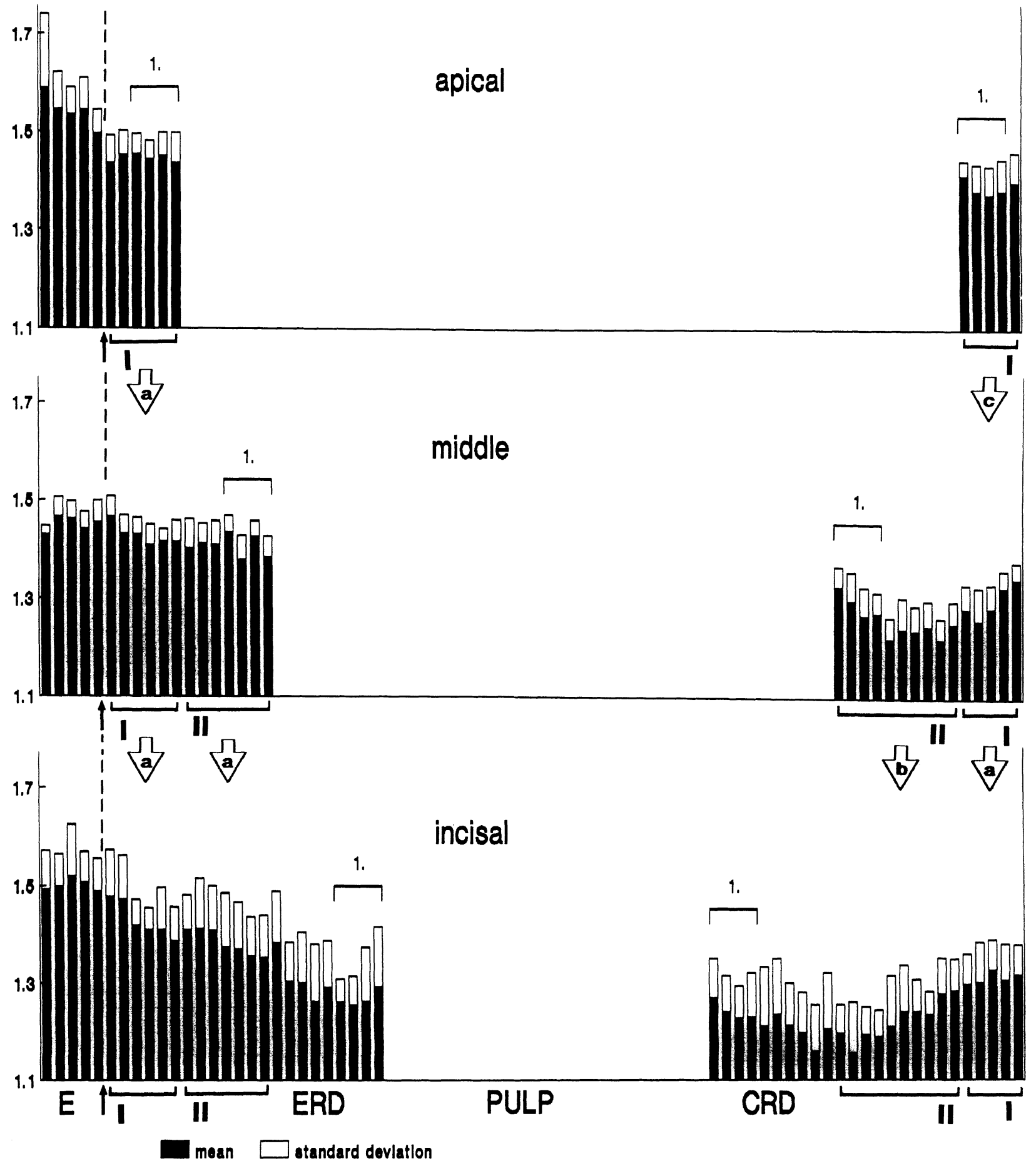

Fig. 3 - Ca/P molar ratio along the mid-sagittal line (see Fig. 1) of the apical, middle, and incisal cross-sections. Measurements were taken at $25-\mu \mathrm{m}$ intervals (mean + S.D.; $\mathrm{n}=10$ ). $\mathrm{E}=$ enamel; closed arrows = dentin-enamel junction. $\mathrm{I}=$ outer dentin zone; $\mathrm{II}=$ middle dentin zone; 1 . $=$ dentin zone most adjacent to the pulp. The open arrows indicate sequential maturation stages of the dentin [(a) N.S.; (b) $p<0.05 ;$ (c) $p<0.01$ ] . The measurements of pre-dentin and cementum are not presented in this Fig.

plained in two ways. The high negative correlation between $\mathrm{Mg}$ and $\mathrm{Ca}$ could signify that $\mathrm{Mg}$ is actually replacing $\mathrm{Ca}$ in pre-existent mineral crystallites. Another explanation is offered by the results of our previous work on the rat, which indicated that older dentin is considerably harder and denser and contains more mineral than younger dentin (Steinfort et al., 1990). Thus, it would seem that the increase of $\mathrm{Mg}$ in aging dentin is the result of the influx of a newly formed Mg-containing mineral, 
which may be related to changes in the odontoblasts. The finding that the $\mathrm{Mg}$ enrichment in the central dentin core is more prominent than that observed in the outer and middle zones may support this view.

In calcified tissues, magnesium may be bound to phosphate (Glick, 1981; Featherstone et al., 1983; Terpstra and Driessens, 1986) or to carbonate. In the latter case, magnesium and carbonate may exist as impurities at the surfaces of hydroxyapatite crystals (Hiller et al., 1975) or as a separate mineral phase (Driessens and Verbeeck, 1985). Although it has been shown that carbonate occurs in bovine dentin (Quint et al., 1980), we have not been able to determine its presence and distribution in the rat incisor by the methods used. Consequently, it is not possible to draw conclusions with respect to the binding of magnesium to either phosphate or carbonate. On the other hand, on the assumption that all magnesium would be bound to carbonate, this would leave unexplained the low $\mathrm{Ca} / \mathrm{P}$ ratio and the high negative correlation between the $\mathrm{Mg} / \mathrm{P}$ and $\mathrm{Ca} / \mathrm{P}$ ratios. Thus, we consider it likely that a considerable amount of magnesium is bound to phosphate, either as magnesium-substituted hydroxyapatite at the surfaces of the crystallites or as a separate mineral phase.

Finally, it is interesting that the increasing amount of magnesium in aging rat incisor dentin deviates from what is seen in some other mineralizing tissues. As time progresses, the $\mathrm{Mg} / \mathrm{Ca}$ ratio in cutaneous calcinosis, fracture callus, and mineralizing turkey tendon decreases (see "Introduction"). A similar decrease is found during early maturation of rat incisor enamel (Hiller et al., 1975), whereas in bovine enamel, an initial increase is followed by a decrease (Robinson et al., 1984). From this we conclude that the relationship between aging and magnesium content is variable and depends upon the type of tissue studied.

\section{REFERENCES}

BASTIN, G.F. and HEIJLIGERS, H.J.M. (1990): Quantitative Electron Probe Microanalysis of Ultra-Light Elements (Boron-Oxygen), Scanning 12:225-236.

BEERTSEN, W. and NIEHOF, A. (1986): Root-Analogue Versus Crown-Analogue Dentin: A Radioautographic and Ultrastructural Investigation of the Mouse Incisor, Anat Rec 215:106-118.

BEERTSEN, W.; NIEHOF, A.; and EVERTS, V. (1985): Effects of 1-hydroxyethylidene-1,1-bisphosphonate (HEBP) on the Formation of Dentin and the Periodontal Attachment Apparatus in the Mouse, J Anat 174:83-103.

DRIESSENS, F.C.M. and VERBEECK, R.M.H. (1985): Dolomite as a Possible Magnesium-containing Phase in Human Tooth Enamel, Calcif Tissue Int 37:376-380.

FEATHERSTONE, J.D.B.; MAYER, I.; DRIESSENS, F.C.M.; VERBEECK, R.M.H.; and HEIJLIGERS, H.J.M. (1983): Synthetic Apatites Containing $\mathrm{Na}, \mathrm{Mg}$, and $\mathrm{CO}_{3}$ and Their Comparison with Tooth Enamel Mineral, Calcif Tissue Int 35:169-171.

GLICK, P.L. (1981): Identification of Mineral Fractions in Developing Rat Incisors. In: The Chemistry and Biology of Mineralized Connective Tissues, A. Veis, Ed., New York: Elsevier North Holland, pp. 309-311.

HILLER, C.H.; ROBINSON, C.; and WEATHERELL, J.A. (1975): Variations in the Composition of Developing Rat Incisor Enamel, Calcif Tissue Res 18:1-12.

HÖHLING, H.J.; HALL, T.A.; BOYDE, A.; and VON ROSENSTIEL, A.P. (1968): Combined Electron Probe and Electron Diffraction Analysis of Prestages and Early Stages of Dentine Formation in Rat Incisors, Calcif Tissue Res 2: suppl., 5-5A.

JOHNSON, A.R. (1972): Strontium, Calcium, Magnesium, and
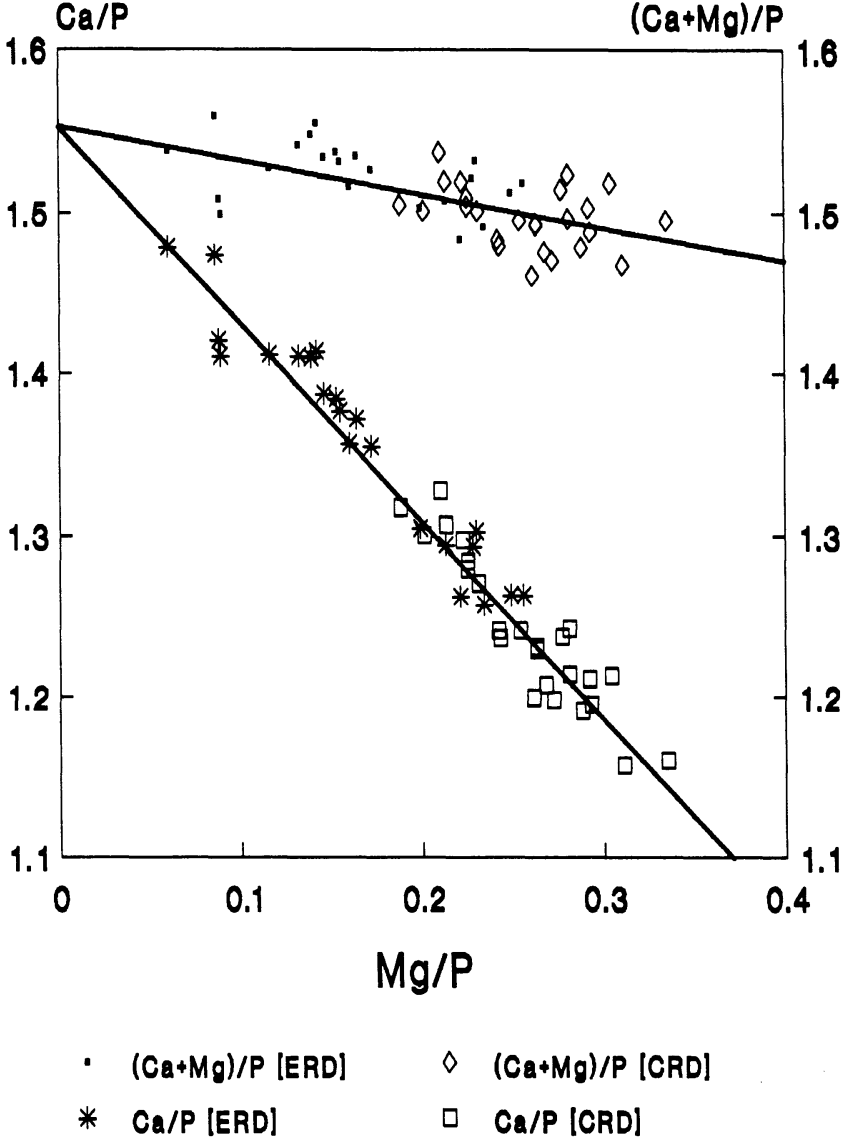

Fig. $4-\mathrm{Ca} / \mathrm{P}$ and $(\mathrm{Ca}+\mathrm{Mg}) / \mathrm{P}$ plotted against $\mathrm{Mg} / \mathrm{P}$ (values obtained at $25-\mu \mathrm{m}$ intervals, along the mid-sagittal line at the incisal level; ERD plus CRD).

Phosphorus Content of Rat Incisors as Determined by Electron Microprobe Analysis, J Dent Res 51:115-121.

ROBINSON, C.; HALLSWORTH, A.S.; and KIRKHAM, J. (1984): Distribution and Uptake of Magnesium by Developing Deciduous Bovine Incisor Enamel, Arch Oral Biol 29:479-482.

QUINT, P.; ALTHOFF, J.; HÖHLING, H.J.; BOYDE, A.; and LAABS, W.A. (1980): Characteristic Molar Ratios of Magnesium, Carbon Dioxide, Calcium and Phosphorus in the Mineralizing Fracture Callus and Predentine, Calcif Tissue Int 32:257261.

SHAW, J.H. and YEN, P.K.-J. (1972): Sodium, Potassium, and Magnesium Concentrations in the Enamel and Dentin of Human and Rhesus Monkey Teeth, $J$ Dent Res 51:95-101.

STEINFORT, J.; VAN DEN BOS, T.; and BEERTSEN, W. (1989): Differences between Enamel-related and Cementum-rclated Dentin in the Rat Incisor with Special Emphasis on the Phosphoproteins, $J$ Biol Chem 264:2840-2845.

STEINFORT, J.; DEBLAUWE, B.M.; and BEERTSEN, W. (1990): The Inorganic Components of Cementum- and Enamel-related Dentin in the Rat Incisor, $J$ Dent Res 69:1287-1292.

TERPSTRA, R.A. and DRIESSENS, F.C.M. (1986): Magnesium in Tooth Enamel and Synthetic Apatites, Calcif Tissue Int 39:348354.

TOCHON-DANGUY, H.J.; GEOFFREY, M.; BOIVIN, G.; and BAUD, C.A. (1978): Mineral Substance of Bone Tissue and of Experimental Cutaneous Calcinosis in Rats: Chemical Analysis and ESR Study, Calcif Tissue Res 26:259-265. 